\title{
On the role of tropopause folds in summertime tropospheric ozone over the eastern Mediterranean and the Middle East
}

\author{
Dimitris Akritidis ${ }^{1,2}$, Andrea Pozzer ${ }^{1}$, Prodromos Zanis ${ }^{2}$, Evangelos Tyrlis $^{3}$, Bojan Škerlak ${ }^{4}$, Michael Sprenger ${ }^{4}$, and \\ Jos Lelieveld ${ }^{1,3}$ \\ ${ }^{1}$ Max Planck Institute for Chemistry, Mainz, Germany \\ ${ }^{2}$ Department of Meteorology and Climatology, School of Geology, Aristotle University of Thessaloniki, Thessaloniki, Greece \\ ${ }^{3}$ Energy, Environment and Water Research Center, The Cyprus Institute, Nicosia, Cyprus \\ ${ }^{4}$ Institute for Atmospheric and Climate Science, ETH Zurich, Zurich, Switzerland \\ Correspondence to: Dimitris Akritidis (dakritid@geo.auth.gr)
}

Received: 22 June 2016 - Published in Atmos. Chem. Phys. Discuss.: 13 July 2016

Revised: 19 October 2016 - Accepted: 19 October 2016 - Published: 11 November 2016

\begin{abstract}
We study the contribution of tropopause folds in the summertime pool of tropospheric ozone over the eastern Mediterranean and the Middle East (EMME) with the aid of the ECHAM5/MESSy Atmospheric Chemistry (EMAC) model. Tropopause fold events in EMAC simulations were identified with a 3-D labeling algorithm that detects folds at grid points where multiple crossings of the dynamical tropopause are computed. Subsequently the events featuring the largest horizontal and vertical extent were selected for further study. For the selection of these events we identified a significant contribution of the stratospheric ozone reservoir to the high concentrations of ozone in the middle and lower free troposphere over the EMME. A distinct increase of ozone is found over the EMME in the middle troposphere during summer as a result of the fold activity, shifting towards the southeast and decreasing altitude. We find that the interannual variability of near-surface ozone over the eastern Mediterranean (EM) during summer is related to that of both tropopause folds and ozone in the free troposphere.
\end{abstract}

\section{Introduction}

Tropospheric ozone is a key species controlling the oxidation capacity of the troposphere (Crutzen, 1988; Penkett, 1988), while it acts as a greenhouse gas in terms of radiative forcing at the earth's surface (Solomon et al., 2007). Compared to ozone near the surface, ozone in the free troposphere can be transported over greater distances due to its relatively longer lifetime and the higher wind velocities. Moreover, owing to its high radiative forcing efficiency in the upper troposphere, ozone concentration changes have proportionally greater impact on climate compared to the lower troposphere (Lacis et al., 1990). The main sources of ozone in the troposphere are (i) photochemical production through a sequence of reactions from its precursors (nitrogen oxide, volatile organic compounds, carbon monoxide and methane) (Crutzen, 1974) and (ii) downward transport from the stratosphere (Danielsen, 1968). Although the abundance and distribution of tropospheric ozone are mainly controlled by photochemistry (Lelieveld and Dentener, 2000), the relative contribution of stratospheric ozone to the tropospheric ozone budget can be significant in certain regions (Roelofs and Lelieveld, 1997; Zanis et al., 2014).

The eastern Mediterranean (EM) (approximately $20-35^{\circ} \mathrm{E}$ and $30-45^{\circ} \mathrm{N}$ ) basin is a region of great interest as it is associated with one of the highest levels of background tropospheric ozone around the globe ( $\mathrm{Li}$ et al., 2001; Zerefos et al., 2002). During summer, the region is characterized by cloud-free conditions and high solar radiation intensity, which, along with the polluted air masses arriving from Europe, Africa and Asia (Lelieveld et al., 2002; Kanakidou et al., 2011), result in enhanced photochemical production of ozone. Therefore, air quality standards of the European Union are often violated (Kouvarakis et al., 2002), potentially having a strong impact on regional air quality and climate (Hauglustaine and Brasseur, 2001). Moreover, the summertime circulation over the EM favors the downward trans- 
port throughout the depth of the troposphere (Ziv et al., 2004; Tyrlis et al., 2013; Zanis et al., 2014), while a global hot spot of tropopause fold formation has been identified over the area (Sprenger et al., 2003; Traub and Lelieveld, 2003; Tyrlis et al., 2014; Škerlak et al., 2015).

During recent years many observational studies have focused on the marked enhancement of summertime ozone over the EM, involving analysis of measurement data from rural and baseline stations (Kouvarakis et al., 2000; Kalabokas and Repapis, 2004; Gerasopoulos et al., 2005), field campaigns (Kourtidis et al., 2002; Kalabokas et al., 2013; Tombrou et al., 2015) and satellites (Richards et al., 2013; Doche et al., 2014; Safieddine et al., 2014). There is also a number of modeling studies on the summertime tropospheric ozone buildup over the eastern Mediterranean and the Middle East (EMME) (approximately $20-50^{\circ} \mathrm{E}$ and $20-45^{\circ} \mathrm{N}$ ) in an attempt to unravel the contributing mechanisms (Zerefos et al., 2002; Lelieveld et al., 2009; Liu et al., 2009, 2011; Zanis et al., 2014). Zerefos et al. (2002) showed that the high ozone levels over the EM cannot be controlled through local emissions. Instead, they are mostly influenced by longrange import of air masses, rich in ozone and ozone precursors, from the European continent (in the lower troposphere) (Stohl et al., 2002; Roelofs et al., 2003) and from North America and Asia (at higher altitudes) (Lelieveld et al., 2002). Richards et al. (2013) employed the TOMCAT 3-D chemical transport model to highlight the role of the south Asian monsoon outflow in the high ozone concentrations in the middle and upper troposphere over the EM. During summer, biogenic emissions may influence lower tropospheric ozone via photochemistry (Liakakou et al., 2007) as model estimates suggest that climate warming may intensify biogenic emissions in the region (Im et al., 2011). Finally, the impact of interannual variations in large-scale circulation over the greater region were investigated by Liu et al. (2011). They reported that the interannual variations of ozone transported from Asia and other regions are linked to the position and strength of the subtropical westerly jet over central Asia.

The circulation over the EM during summer is characterized by a sharp east-west pressure gradient with low pressure over the EMME and high pressure over the western Mediterranean and the Balkans. These large-scale synoptic pressure patterns lead to the development of Etesian winds over the Aegean Sea, which are among the most persistent regional wind systems in the world (Carapiperis, 1951; Repapis et al., 1977; Poupkou et al., 2011; Tyrlis et al., 2013; Tyrlis and Lelieveld, 2013; Anagnostopoulou et al., 2014). The dynamics of the Etesians are tightly interwoven with the largescale dynamics observed over the EM. In fact, the midlatitude westerlies interact with a zonally asymmetric structure induced by the south Asian monsoon as a result of westwardpropagating Rossby waves excited by monsoon convective activity (Rodwell and Hoskins, 1996, 2001; Tyrlis et al., 2013). This, in turn, results in large-scale subsidence over the EM. Subsidence can be further enhanced over southeast- ern Europe through the diabatic enhancement mechanism described by Rodwell and Hoskins (1996).

Stratosphere-to-troposphere transport (STT) is considered a process of great importance for the EM region, as it influences tropospheric ozone levels during summer (Zanis et al., 2014). Zanis et al. (2014) reported that STT processes feed stratospheric ozone into the upper troposphere, and subsequently the ozone-rich air masses are transported to the lower free-tropospheric levels through the characteristic strong summertime EMME subsidence. The main mechanism for STT events is tropopause folding (Stohl et al., 2003), developed by the ageostrophic flow in the jet stream entrance, which is associated with stratospheric intrusions into the troposphere (Danielsen and Mohnen, 1977). Tropopause folding events mainly occur at midlatitudes, and are characterized by tongues of anomalously high potential vorticity (PV), high ozone and low water vapor mixing ratios (Holton et al., 1995). Subsequent to transport into the troposphere, air with stratospheric origin is quasi-adiabatically stirred by largescale cyclonic and anticyclonic disturbances, which may lead to the formation of elongated streamers or isolated coherent structures. These can further dissipate and cascade down to smaller scales by non-conservative processes (such as radiative cooling/heating and turbulence), thus leading to irreversible mixing with the surrounding air (Shapiro, 1980; Appenzeller and Davies, 1992; Forster and Wirth, 2000).

Recently, Tyrlis et al. (2014) underscored the global hot spot of summertime fold activity between the EM and central Asia, in the vicinity of the subtropical jet, confirming the earlier findings of Sprenger et al. (2003). Moreover, they reported a striking dynamical link between fold activity over the EMME and the intensity of the south Asian monsoon on interannual timescales. Convective activity over South Asia was found to regulate upper-level baroclinicity over the EMME and thus the fold occurrence over the region. In summary, the aforementioned studies show that STT events often occur in the EM region and in cases of deep stratospheric intrusions can reach the lower troposphere (Zanis et al., 2003; Gerasopoulos et al., 2006; Akritidis et al., 2010).

Model sensitivity studies suggest that relatively high horizontal resolution might be beneficial for the representation of tropopause fold events and the associated intrusion of stratospheric ozone into the troposphere (Kentarchos et al., 2000). Lin et al. (2012) showed that a global high-resolution $(50 \mathrm{~km} \times 50 \mathrm{~km})$ chemistry-climate model (GFDL AM3) captures the observed layered features and sharp ozone gradients of deep stratospheric intrusions. Moreover, Lin et al. (2015), carrying out sensitivity studies with the GFDL AM3 model, pointed out that using a finer horizontal resolution of $50 \mathrm{~km} \times 50 \mathrm{~km}$ revealed an improvement in the reproduction of the day-to-day variability in the upper troposphere, as tropopause fold filamentary structures are better resolved in the finer model resolution simulations. Nevertheless, they suggested that the multidecadal hindcast simulations with the coarser resolution of $200 \mathrm{~km} \times 200 \mathrm{~km}$ were also found to be 
suitable for quantifying the regional-scale interannual variability of stratospheric influence on lower tropospheric ozone over the western United States.

This study aims to assess the contribution of tropopause folds to the summertime pool of high tropospheric ozone concentrations over the EMME. More specifically, the downward transport of ozone-rich air of stratospheric origin is determined with the ECHAM5/MESSy Atmospheric Chemistry (EMAC) model. Another aspect explored here is to what extent the interannual variability of near-surface ozone over the EM is controlled by the interannual variability of tropopause fold frequency. Section 2 describes the basic features of the EMAC model, elucidates how tropopause folds are identified with the use of a 3-D labeling algorithm and presents the methodology applied to select the more intense folding events. Section 3 presents the main results regarding the contribution of tropopause folds to tropospheric ozone. In particular, the link between the interannual variability of near-surface ozone and that of tropopause fold frequency is investigated. Finally, Sect. 4 summarizes the main conclusions.

\section{EMAC model description and methodology}

\subsection{EMAC model description}

The ECHAM/MESSy Atmospheric Chemistry (EMAC) model is a numerical chemistry and climate simulation system that includes submodels describing tropospheric and middle atmosphere processes and their interaction with oceans, land and human influences (Jöckel et al., 2016). It uses the second version of the Modular Earth Submodel System (MESSy2) to link multi-institutional computer codes. The core atmospheric model is the fifth-generation European Centre Hamburg general circulation model (ECHAM5) (Roeckner et al., 2006). In this work the model results from simulation RC1SD-base-10 of the ESCiMo project (Jöckel et al., 2016) are used. Detailed information on the model setup and comparison with observations can be found in Jöckel et al. (2016), while here only basic information on the simulation will be summarized.

The model results were obtained with ECHAM5 version 5.3.02 and MESSy version 2.51, with a T42L90MAresolution, i.e., with a spherical truncation of T42 (corresponding to a quadratic Gaussian grid of approx. 2.8 by $2.8^{\circ}$ in latitude and longitude) and 90 vertical hybrid pressure levels up to $0.01 \mathrm{hPa}$. The dynamics of the general circulation model were weakly nudged by Newtonian relaxation towards ERA-Interim reanalysis data (Dee et al., 2011). Model outputs were produced with a 10-hourly temporal resolution.
The simulation RC1SD-base-10 was selected among the ESCiMo simulations because it (i) has been weakly nudged to reproduce "observed" atmospheric dynamics, (ii) has high resolution near the tropopause $(\simeq 17$ levels between 400 and $100 \mathrm{hPa}$ ) for realistic tropopause fold representation and (iii) is the closest to the one recommended by Jöckel et al. (2016) with sufficient temporal coverage for climatological study (1979-2013).

Furthermore, besides ozone chemistry, EMAC carries a tracer for stratospheric ozone (denoted by $\mathrm{O}_{3} \mathrm{~s}$ ), providing a diagnostic in the investigation of the stratospheric contribution to tropospheric ozone. $\mathrm{O}_{3} \mathrm{~s}$ is set to ozone values in the stratosphere and follows the transport and destruction processes of ozone in the troposphere. When $\mathrm{O}_{3} \mathrm{~s}$ reenters the stratosphere it is reinitialized at stratospheric values; however, since it is initialized above $100 \mathrm{hPa}$, only a very small fraction is recirculated by multiple crossings of the tropopause (Roelofs and Lelieveld, 1997).

Figure 1 compares ozonesonde average JJA profiles over Ankara, Turkey $\left(32.86^{\circ} \mathrm{E}, 39.97^{\circ} \mathrm{N}\right)$, during the period 1994-2012, obtained from the World Ozone and Ultraviolet Radiation Data Center (WOUDC) (WMO/GAW Ozone Monitoring Community, 2015), and the respective EMACsimulated ozone profiles. The corresponding standard deviations are also shown. Overall, the model seems to adequately capture the summertime ozone concentrations throughout the troposphere, although there is a tendency to overestimate them in the middle-upper troposphere. While the modeled ozone variability, as described by the standard deviation, falls within that of the observations, low ozone events tend to be underestimated.

\subsection{Fold identification algorithm}

Tropopause folds are detected in the EMAC model output with the fold identification algorithm by Sprenger et al. (2003), which recently has been improved by Śkerlak et al. (2014). A 3-D labeling algorithm is applied to classify the air masses into the following five categories: (1) tropospheric, (2) stratospheric, (3) stratospheric cut-off, (4) tropospheric cut-off and (5) surface-bound PV anomaly. In more detail, the algorithm uses 3-D fields of potential vorticity, potential temperature and specific humidity, and subsequently assigns one of the aforementioned labels to all grid points. A tropopause fold at a grid point is designated where multiple crossings of the dynamical tropopause (2 PVU isosurface) are identified in instantaneous vertical profiles of the label field (for more details see Fig. 1 from Škerlak et al., 2015). Therefore, the 3-D labeling algorithm outputs are 10hourly binary (1: fold, 0 : no fold) data for every grid point and time step, while the average value of these data for a certain period represents the tropopause fold frequency for the corresponding period. Moreover, for every grid point where a tropopause fold is detected, the upper $\left(p_{\mathrm{U}}\right)$, middle $\left(p_{\mathrm{M}}\right)$ and lower $\left(p_{\mathrm{L}}\right)$ pressure levels of tropopause crossings are 


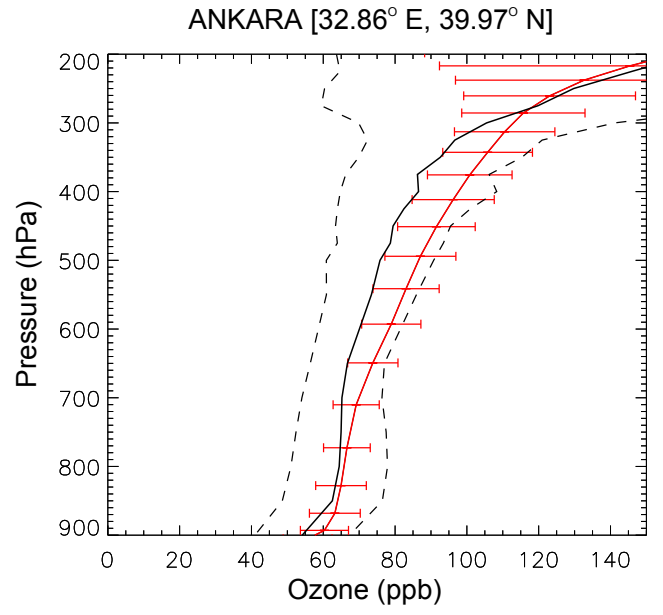

Figure 1. Vertical profiles of JJA ozone (mixing ratios) over Ankara (STN348) for the period 1994-2012. The solid black line represents observations, and the red line refers to EMAC-simulated ozone. The dashed black lines show the observed standard deviations, and the red bars show the model standard deviations.

determined, and subsequently the pressure difference $\Delta p=$ $p_{\mathrm{M}}-p_{\mathrm{U}}$ between the upper and middle tropopause crossings is calculated (for more details see Fig. 1 of Tyrlis et al., 2014). The above pressure difference reveals the vertical extent of the tropopause fold (Sprenger et al., 2003; Tyrlis et al., 2014; Škerlak et al., 2015).

To evaluate the ability of the EMAC model to capture tropopause fold activity, we compare results with the findings of Tyrlis et al. (2014), based on the ERA-Interim reanalysis data. The monthly mean climatology (1979-2012) of shallow $(50 \leq \Delta p<200 \mathrm{hPa})$, medium $(200 \leq \Delta p<350 \mathrm{hPa})$ and deep $(\Delta p \geq 350 \mathrm{hPa})$ fold frequency during several months is depicted in Fig. S1 (in the Supplement), for intercomparison with Fig. 2 of Tyrlis et al. (2014). Both temporal and spatial patterns of EMAC-simulated shallow (more frequent) and medium fold frequencies are found to be in good agreement with the ERA-Interim reanalysis data. The very rare occurrence of deep folds in the ERA-Interim data (with a peak frequency of about $0.1 \%$ ) is not reproduced by EMAC, probably due to its coarser horizontal resolution. Figure 2 presents the summer (JJA) climatology of the total folding activity calculated from EMAC simulations. A distinct hot spot of tropopause fold activity is found over the EMME region, as a result of the dynamical interaction between the subtropical jet and the Asian monsoon anticyclone (Tyrlis et al., 2014), with maximum values of the total fold frequency up to $15 \%$ over southern Turkey. The above pattern of summertime fold frequency is in line with the results of recent studies (Tyrlis et al., 2014; Škerlak et al., 2015) based on the ERA-Interim reanalysis data.

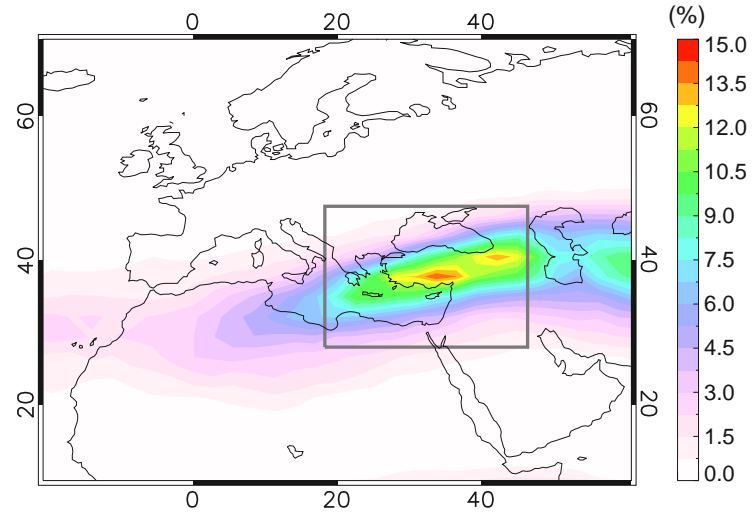

Figure 2. Mean tropopause fold frequencies (\%) during summer for the period 1979-2013 from EMAC simulations. The box indicates the domain of interest (see Sect. 2.3).

\subsection{Selection of fold events}

In order to study the impact of tropopause folds on summertime tropospheric ozone over the EMME, we selected the most intense summer fold events throughout the period 1979-2013. The influence of tropopause folds on tropospheric ozone over the EMME depends on both the fraction of grid points that exhibit a fold and the vertical extent of the folds. For this purpose, the fold coverage (hereafter FC) within the domain of interest (see marked region in Fig. 2) is calculated, as well as the average vertical extent of the folds, i.e., the average of $\Delta p$ values only for grid points exhibiting a fold. This is done for every summer time step of the period 1979-2013. Based on FC and $\Delta p$, time steps are selected when the EMME region is potentially influenced by folds. Figure 3 shows the distribution of $\mathrm{FC}$ and $\Delta p$, and the thresholds used to identify intense folds $(\mathrm{FC}=5.71 \%$ and $\Delta p=60.89 \mathrm{hPa}$ ). Thereby, the thresholds are given as the median values of the population of summer time steps during 1979-2013, but only when at least one grid point with fold is detected inside the domain of interest. Thus, 1866 summer time steps are selected (see upper-right quartile in Fig. 3), representing $24 \%$ of the total summer time steps of the examined period. The intense folds are hereafter called fold events for brevity.

\section{Results}

\subsection{Tropospheric ozone distribution during folds}

Figure 4 (left) shows the composites of ozone concentrations simulated by EMAC that are averaged over the selected fold events. It reveals a pool of high ozone concentrations over the EMME region throughout the free troposphere. More specifically, the highest ozone concentrations in the middle troposphere (Fig. 4a, b and c) are found over the broader EMME 


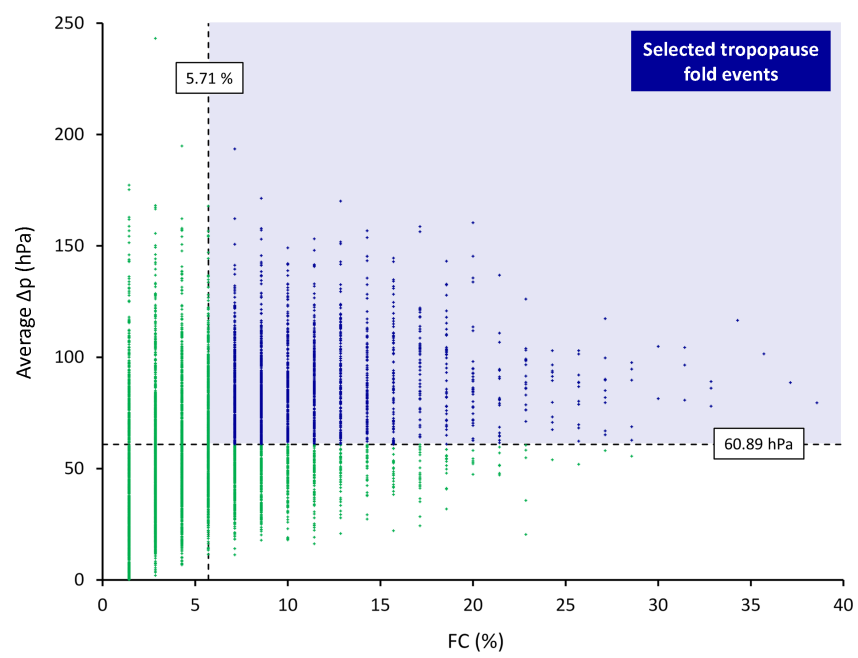

Figure 3. Scatter plot distributions of FC and average $\Delta p$ for the summer time steps of the period 1979-2013 over the domain of interest (box in Fig. 2).

region. This high ozone pattern is also evident in the lower troposphere (Fig. 4d), extending geographically to the Persian Gulf. It should be mentioned that this pool of enhanced tropospheric ozone concentrations over the EMME is also seen when all summer time steps are included (not shown). Hence, it is a persistent feature mainly driven by the summertime circulation and the photochemical regime over the region in agreement with the study by Zanis et al. (2014).

In order to quantify the contribution of stratospheric ozone to the high tropospheric ozone levels during the selected fold events, the ratio of $\mathrm{O}_{3}$ s to $\mathrm{O}_{3}$ is investigated. Figure 4 (right) presents the average of the $\mathrm{O}_{3}$ s to $\mathrm{O}_{3}$ ratio during the selected fold events at various mid-tropospheric to lower tropospheric levels. The percentage (\%) of ozone originating from the stratosphere is particularly high over the EMME region, reaching values of about $30-50 \%$ in the middle troposphere (Fig. $4 \mathrm{e}, \mathrm{f}$ and $\mathrm{g}$ ). A significant contribution of up to $36 \%$ is conspicuous, even in the lower free troposphere (Fig. 4h).

\subsection{The impact of tropopause folds on summertime tropospheric ozone}

The anomalies of $\mathrm{O}_{3}$ and $\mathrm{O}_{3}$ s presented hereafter are calculated as the differences between the average concentrations during fold events (average over 1866 time steps) and the average concentrations during the remainder summer time steps (average over 5864 time steps). The role of tropopause folds in high tropospheric ozone levels during summer over the EMME is explored next. To this end, anomalies of the average ozone concentrations during fold events are constructed with respect to the concentrations during the rest of summer time steps (Fig. 5, left). A distinct positive pattern is found in the middle troposphere (Fig. 5a, b and c), mainly over the EMME region, revealing an increase of ozone up to
$7 \mathrm{ppb}$ due to fold activity. An increase of ozone is also clear at $700 \mathrm{hPa}$ (Fig. 5d), with mixing ratios of up to $4 \mathrm{ppb}$. During extreme events (above the 95th percentile of $\mathrm{O}_{3}$ concentrations during fold events), the range of $\mathrm{O}_{3}$ enhancement is found to be 19-33, 16-31, 17-24 and 11-19 ppb at 400, 500, 600 and $700 \mathrm{hPa}$ respectively (Fig. S2 in the Supplement).

The above-mentioned enhancement in ozone levels is due to downward transport of ozone from the stratosphere through the folding process, as can be inferred from the respective anomalies for $\mathrm{O}_{3}$ s shown in Fig. 5 (right). Similar positive patterns, both quantitatively and spatially, are found for all examined pressure levels (Fig. 5e, f, g and h), supporting the hypothesis that the increase of tropospheric ozone during the selected fold events is mainly attributed to the transport of ozone of stratospheric origin. Analogous results with the same spatial features but less pronounced positive deviations were obtained by analyzing the anomalies of both $\mathrm{O}_{3}$ and $\mathrm{O}_{3}$ s during the selected summer fold events with respect to their summer climatologies (not shown).

It should be mentioned that different definitions of stratospheric ozone tracer may have implications for the estimated stratospheric contribution, as has been pointed out by Zhang et al. (2014). More specifically, a doubling of the diagnosed stratospheric ozone influence was found in GEOS-Chem simulations when the produced ozone in the troposphere, which was temporarily transported above the tropopause, was also considered as stratospheric (Lin et al., 2012 approach). The amount of ozone that is recirculated across the tropopause in the model depends on the vertical resolution. Thus, following the approach by Lin et al. (2012) is likely to yield an upper limit to the stratospheric contribution to tropospheric ozone in our results. Nevertheless, because the presently used middle atmosphere version of the EMAC model has relatively high resolution in the upper troposphere and lower stratosphere (about $500 \mathrm{~m}$ ), and because we initialize $\mathrm{O}_{3} \mathrm{~s}$ well above the tropopause $(100 \mathrm{hPa})$, we expect this effect to be small.

\subsection{Vertical structure and transport}

The vertical structure and transport of $\mathrm{O}_{3} \mathrm{~s}$ in the troposphere and the role of tropopause folds is best studied in latitudepressure and longitude-pressure cross sections of $\mathrm{O}_{3}$ s. Figure 6 shows such composite sections for $\mathrm{O}_{3}$ s during the selected folds. The main feature depicted in the latitudepressure cross section $30^{\circ} \mathrm{E}$ (Fig. 6a) is a remarkable southward and downward intrusion of ozone-rich air towards the lower free troposphere (approximately down to $800 \mathrm{hPa}$ ) within the $15-40^{\circ} \mathrm{N}$ latitude band. The longitude-pressure cross section of $\mathrm{O}_{3} \mathrm{~s}$ at a latitude of $35^{\circ} \mathrm{N}$ (Fig. 6b) suggests a similar descending structure of high $\mathrm{O}_{3}$ s values in a westeast orientation, over the $20-45^{\circ} \mathrm{E}$ longitude band. Thus, both vertical cross sections reveal the downward transport pathways of stratospheric air masses, resembling the southeastern and downward movement in the vicinity of sharply 


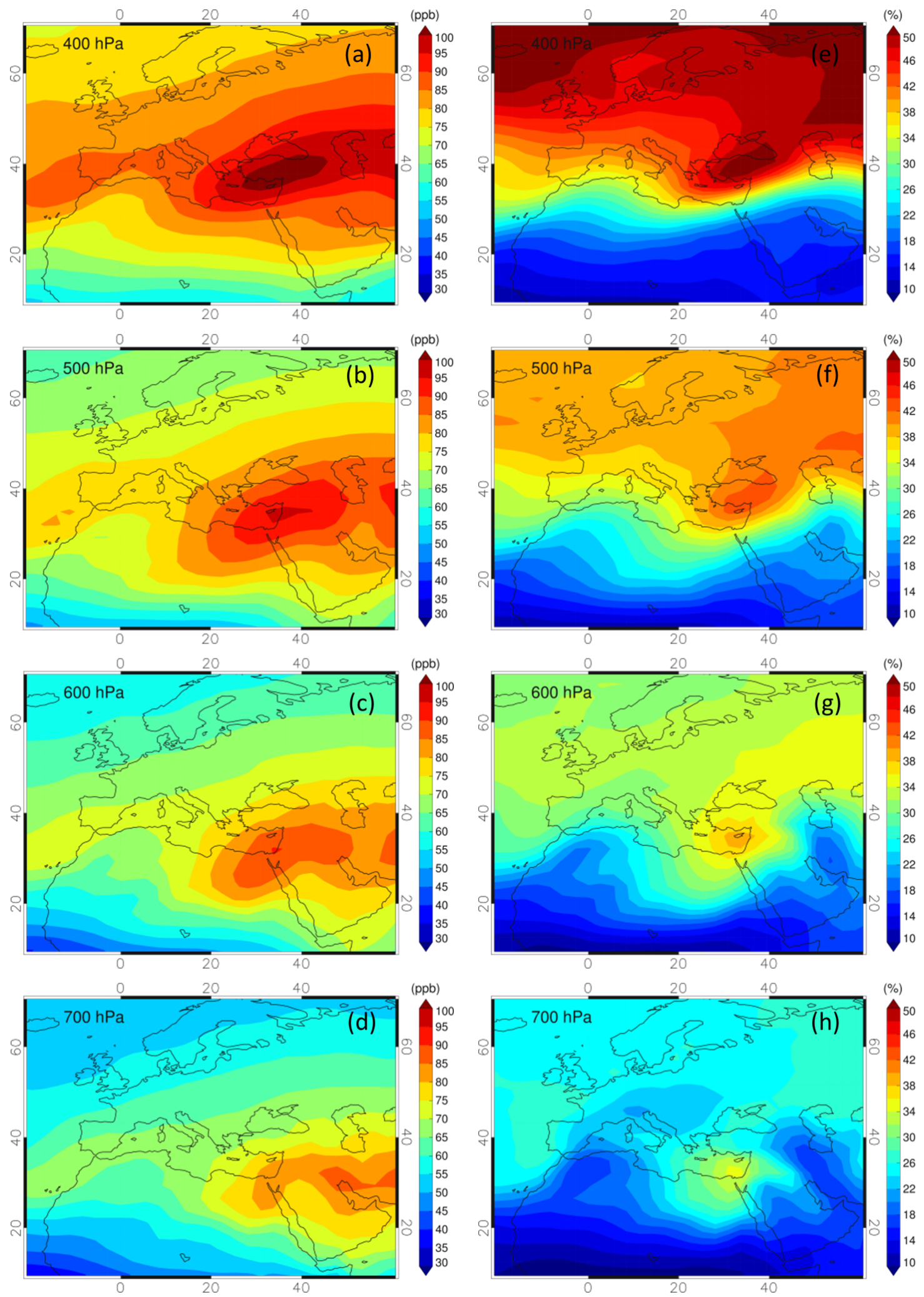

Figure 4. Spatial distribution of EMAC-simulated ozone (ppb) and stratospheric ozone contribution (\%) averaged over the selected fold events of the period 1979-2013 at $400 \mathrm{hPa}(\mathbf{a}, \mathbf{e}), 500 \mathrm{hPa}(\mathbf{b}, \mathbf{f}), 600 \mathrm{hPa}(\mathbf{c}, \mathbf{g})$ and $700 \mathrm{hPa}(\mathbf{d}, \mathbf{h})$. 

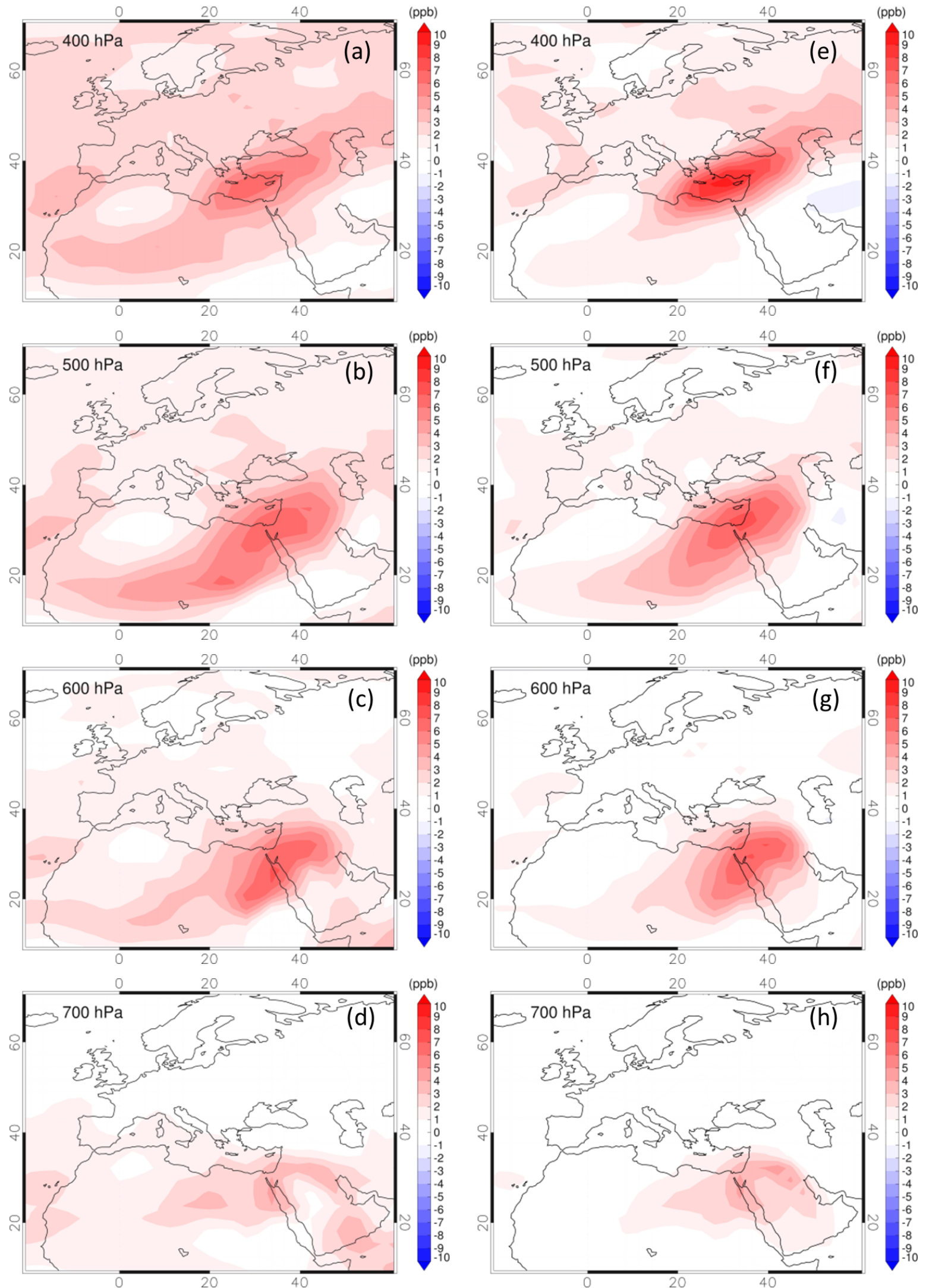

Figure 5. Anomalies of EMAC-simulated ozone (left) and stratospheric ozone tracer (right) during the selected fold events from the remainder summer time steps at $400 \mathrm{hPa}(\mathbf{a}, \mathbf{e}), 500 \mathrm{hPa}(\mathbf{b}, \mathbf{f}), 600 \mathrm{hPa}(\mathbf{c}, \mathbf{g})$ and $700 \mathrm{hPa}(\mathbf{d}, \mathbf{h})$. 
(a)

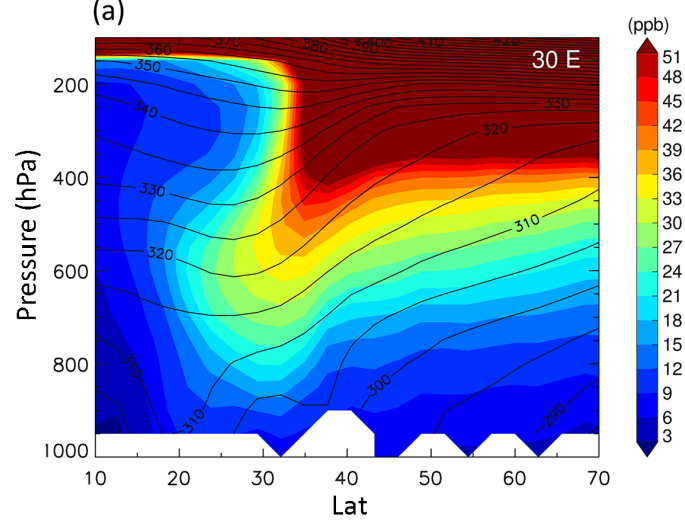

(b)

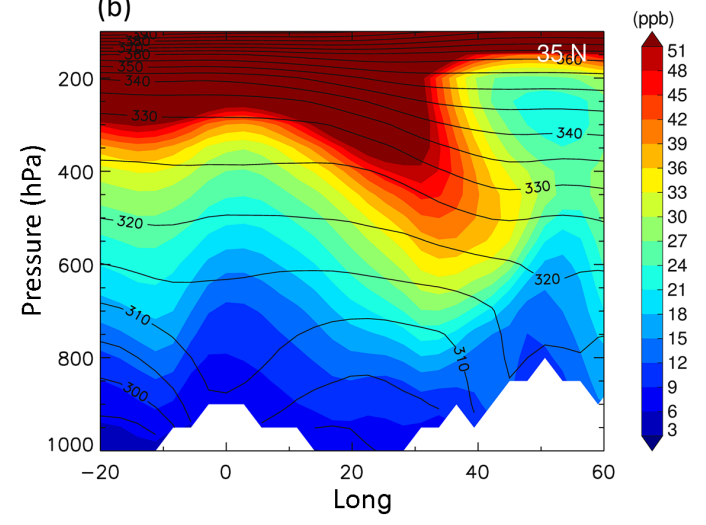

(c)

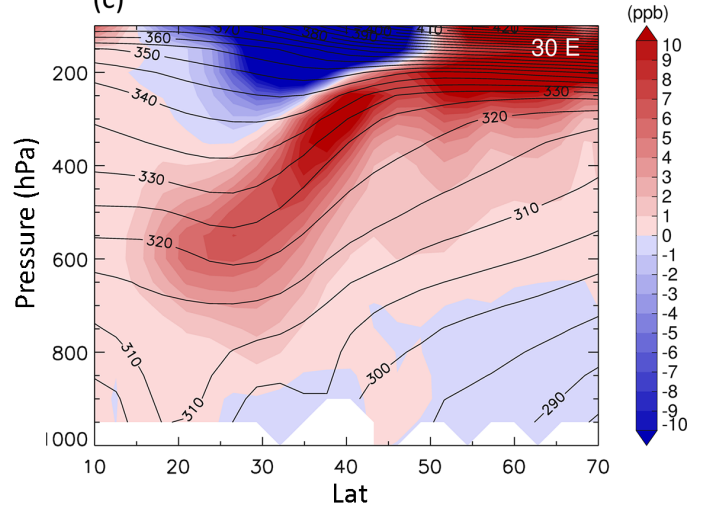

(d)

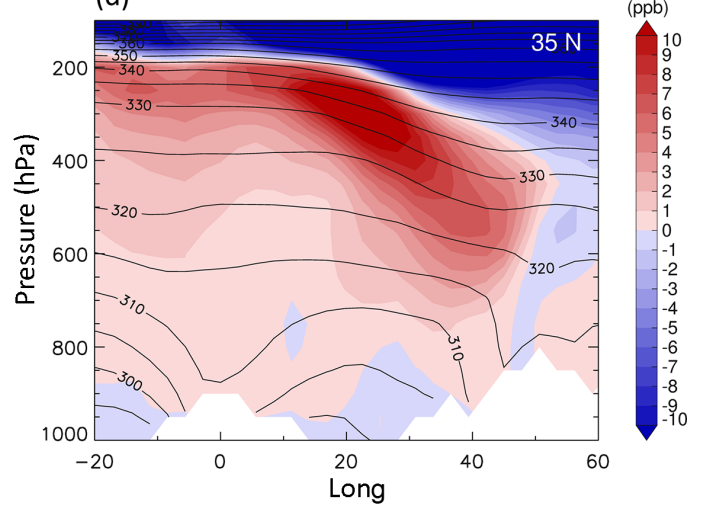

Figure 6. Latitude-pressure cross sections at $30^{\circ} \mathrm{E}$ of (a) $\mathrm{O}_{3} \mathrm{~s}$ during the selected fold events and (c) the anomalies from the remainder of the summer time steps. Longitude-pressure cross sections at $35^{\circ} \mathrm{N}$ of (b) $\mathrm{O}_{3}$ s during the selected fold events and (d) the anomalies from the rest of the summer time steps. Black contours denote potential temperature (K) during the selected fold events.

sloping isentropes as illustrated in previous stratospheric intrusion case studies over the area (Galani et al., 2003).

To further explore the contribution of tropopause folds to the summertime tropospheric ozone pool over the EMME region, we illustrate the respective vertical cross sections of the anomalies of $\mathrm{O}_{3}$ s during the selected fold events with respect to the rest of summer time steps (Fig. $6 \mathrm{c}$ and d). The anomalies of EMAC-simulated $\mathrm{O}_{3}$ s latitude-pressure cross sections at a longitude of $30^{\circ} \mathrm{E}$ (Fig. 6c) indicate a clear increase of $\mathrm{O}_{3} \mathrm{~s}$ throughout the free troposphere during the selected fold events, with values of up to $10 \mathrm{ppb}$ in the upper troposphere, which decreases towards lower tropospheric levels following the sloping isentropes. The same picture emerges from the longitude-pressure cross section at a latitude of $35^{\circ} \mathrm{N}$ (Fig. 6d).

Figure 7a depicts the vertical profiles of the anomalies of $\mathrm{O}_{3}$ s during the selected fold events with respect to the rest of the summer time steps for five grid points that are located in a northwest-directed axis over the EMME region (Fig. 7b). A clear positive anomaly of up to $15 \mathrm{ppb}$ is found in the upper troposphere over the Aegean Sea, extending down to roughly $600 \mathrm{hPa}$ (grid point 1). Further southeastwards, the peak of the positive ozone anomaly gradually occurs lower in the free troposphere. For example, at grid point 2 (near to Crete) the maximum anomaly of around $11 \mathrm{ppb}$ at $350 \mathrm{hPa}$ extends down to $700 \mathrm{hPa}$, while grid point 3 indicates a peak anomaly of around $8 \mathrm{ppb}$ at $450 \mathrm{hPa}$, extending down to $800 \mathrm{hPa}$. Further downstream, grid points 4 and 5 reveal peak anomalies of about 8 and $6 \mathrm{ppb}$ at 550 and $600 \mathrm{hPa}$ respectively, extending down to $900 \mathrm{hPa}$ over grid point 5 . This is in agreement with the studies by Zanis et al. (2014) and Tyrlis et al. (2014) that provided evidence of a southeastward migration of the maxima of high-PV and ozone anomalies closer to the surface. This is due to the fact that ozone-rich and high-PV air masses follow the sharply sloping isentropes, in an almost adiabatic fashion, as they spread from the Balkans toward the Levantine region. As also noted by Tyrlis et al. (2014), the deeper but rarer folds are identified over the Levantine region, which is in agreement with the fact that ozone anomalies at lower level are located over this region.

\subsection{Interannual variability}

To investigate the possible impacts of tropopause folds on both tropospheric ozone and near-surface ozone over the EM region, we examined the year-to-year relation between tropopause fold frequency, EMAC-simulated free tropo- 

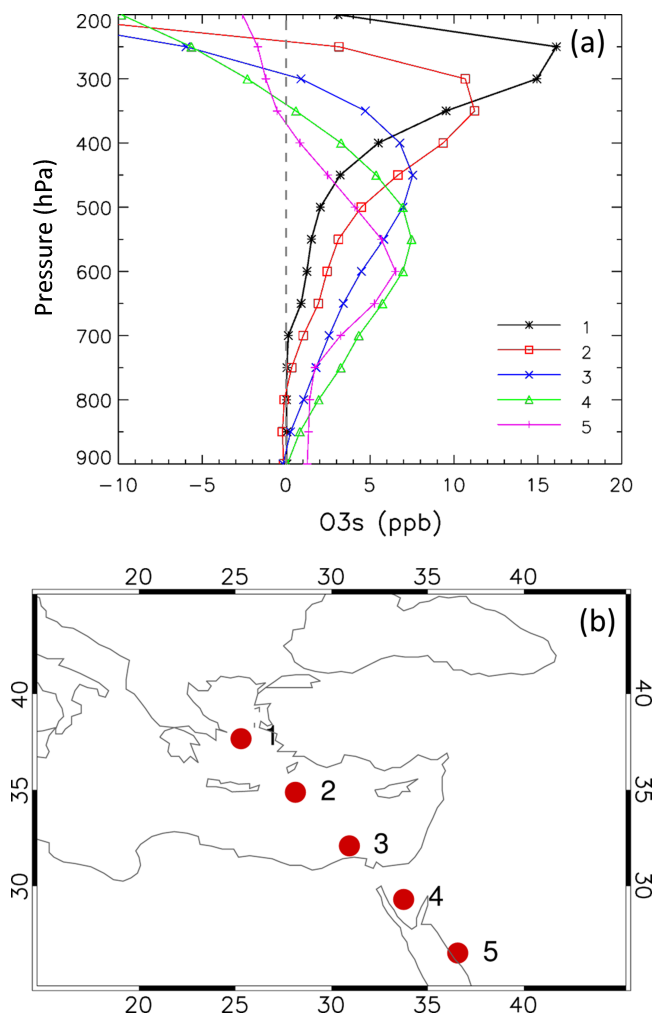

Figure 7. Vertical profiles of the anomalies of EMAC-simulated $\mathrm{O}_{3}$ s during the selected fold events with respect to the rest of summer time steps (a) for five grid points in a northwest direction over the EMME region (b).

spheric ozone and near-surface ozone observations. For this purpose we consider near-surface ozone data from the baseline maritime station at Finokalia, Crete (GR02, 25.67 E, $35.32^{\circ} \mathrm{N}$; see Fig. 9 for location), from the European Monitoring and Evaluation Programme (EMEP) network for the time period 1998-2013. Figure 6b suggests that in the EMAC simulations the contribution of the stratospheric reservoir does not reach the surface in the vicinity of Crete during the selected fold events. However, this could be related to other model processes that partly mask the contribution of downward transport to the near-surface level, such as overestimation of photochemical ozone production related to emission inventories and the coarse horizontal resolution, as well as issues related to the accurate representation of processes that determine the entrainment from the lower free troposphere into the atmospheric boundary layer (Zanis et al., 2014).

Hereafter, the Pearson correlation coefficient is used to quantify the relationship between EMAC ozone, fold frequency and surface ozone observations. Its significance at the $95 \%$ confidence level is assessed based on $t$ test statistics. First, the interannual variability of the mean July-August tropopause fold frequency over a southern Balkan region (hereafter SB, $20-27^{\circ} \mathrm{E}, 37-44^{\circ} \mathrm{N}$ ) is found to be positively correlated at the $95 \%$ significance level with the mean July-

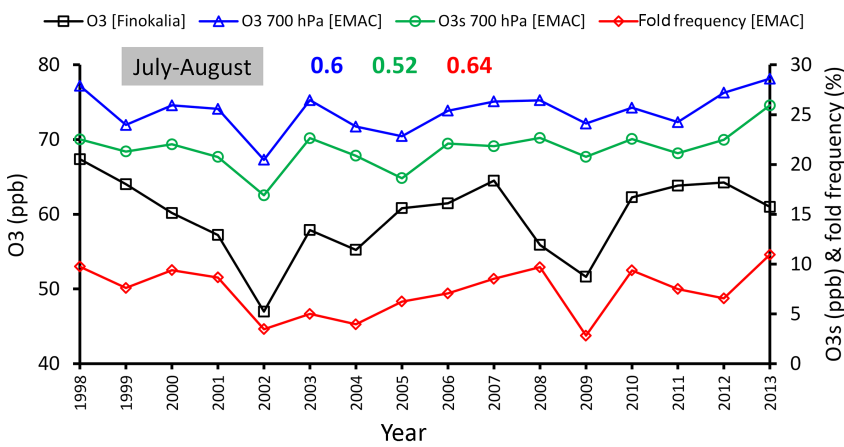

Figure 8. Time series over the period 1998-2013 of July-August average values for observed near-surface ozone at Finokalia Crete (black squares), EMAC-simulated ozone at $700 \mathrm{hPa}$ over EM (blue triangles, $20-30^{\circ} \mathrm{E}, 30-40^{\circ} \mathrm{N}$ ), EMAC-simulated $\mathrm{O}_{3} \mathrm{~s}$ at $700 \mathrm{hPa}$ over EM (green circles, $20-30^{\circ} \mathrm{E}, 30-40^{\circ} \mathrm{N}$ ) and tropopause fold frequency over SB (red diamonds, $20-27^{\circ} \mathrm{E}, 37-44^{\circ} \mathrm{N}$ ). The colored numbers above the lines are the correlation coefficients between July-August average values of near-surface ozone at Finokalia and EMAC-simulated $\mathrm{O}_{3}$ at $700 \mathrm{hPa}$ over EM (blue); EMAC-simulated $\mathrm{O}_{3} \mathrm{~s}$ at $700 \mathrm{hPa}$ over EM (green); tropopause fold frequency over SB (red) respectively.

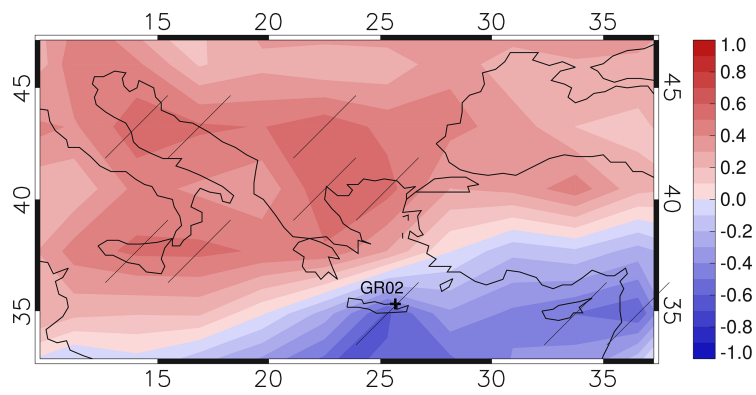

Figure 9. Spatial distribution of the correlation coefficient between July-August average values of near-surface ozone at Finokalia and July-August average values of tropopause fold frequency at each grid point over the period 1998-2013. Areas featuring correlation coefficients that are statistically significant at the $95 \%$ confidence level are hatched.

August EMAC-simulated $\mathrm{O}_{3}$ and $\mathrm{O}_{3} \mathrm{~s}(r=0.69$ and $r=0.65$ respectively) in the lower free troposphere $(700 \mathrm{hPa})$ over the EM (20-30 E, 30-40 N) (Fig. 8). Similarly, the mean JulyAugust ozone concentration measurements at Finokalia are also positively correlated at the $95 \%$ significance level with the mean July-August tropopause fold frequency over SB $(r=0.64)$ (Fig. 8). Moreover, the observed ozone values at Finokalia show a positive correlation at the $95 \%$ significance level with both $\mathrm{O}_{3}$ and $\mathrm{O}_{3}$ s values at $700 \mathrm{hPa}$ over the EM, with values of $r=0.6$ and $r=0.52$ respectively (Fig. 8). All in all, the correlations indicate a link of the observed nearsurface ozone at Finokalia with both tropopause fold frequency and ozone of stratospheric origin at the lower free troposphere. 
The findings above are further supported when we consider the spatial distribution of the correlation coefficient between the mean July-August values of the observed ozone at Finokalia and the tropopause fold frequency at each grid point (Fig. 9). Indeed, positive correlations at the $95 \%$ significance level can be found over northern Greece and the central Mediterranean. The sharp change in the sign of the correlation just to the north of Crete could be interpreted by the morphology of folds and the associated stratospheretroposphere exchange (STE). Typically a fold advances from the northwest towards the southeast and the intrusion of highPV and ozone air that develops also moves downwards and southwards. The fold becomes mature and sooner or later it "breaks", and fragments of high PV can disperse downward. If such patches of high-PV and ozone-rich air survive subsidence towards the surface near Crete, this can only be associated with folding occurring further upstream over the Balkans. This is due the background northwesterly flow over the region and the morphology of intrusions described in Fig. 6.

In order to investigate in more detail the links between ozone of stratospheric origin with both tropopause fold frequency over SB and near-surface ozone at Finokalia, we constructed the corresponding latitude-pressure cross sections at $25^{\circ} \mathrm{E}$ (parallel crossing the island of Crete and the Aegean Sea) of the correlation coefficient (Fig. 10a and b respectively) between the mean July-August interannual time series of the period 1998-2013. Figure 10a indicates a significant positive correlation of the mean July-August tropopause fold frequency over SB with the mean July-August EMACsimulated $\mathrm{O}_{3} \mathrm{~S}$ in the lower free troposphere over the 25$40^{\circ} \mathrm{N}$ latitude band. Similarly, significant positive correlations between the mean July-August values of observed ozone at Finokalia and mean July-August EMAC-simulated $\mathrm{O}_{3} \mathrm{~s}$ are found in the middle and lower troposphere. The vertical structure of the positive correlations in both latitudepressure cross sections in Fig. 10 resembles the structure of the latitude-pressure cross section $25^{\circ} \mathrm{E}$ of $\mathrm{O}_{3} \mathrm{~s}$ (not shown), thus indicating the dynamical nature of the link between both observed near-surface ozone at Finokalia and tropopause fold frequency over SB with EMAC-simulated ozone of stratospheric origin. Nevertheless, no significant correlation is found between the observed and EMAC-simulated nearsurface ozone values at Finokalia, which could be related to overestimated photochemical ozone production in the boundary layer by the model.

Based on the results so far, we infer that the interannual variability of near-surface ozone over the EM is partly governed by the interannual variabilities of tropospheric ozone of stratospheric origin and tropopause folds. This hypothesis is further supported when the trends of both tropopause fold frequency and EMAC-simulated $\mathrm{O}_{3}$ s are considered (Fig. 11). The trends during summer over the period 19792013 were calculated by implementing linear regression analysis on mean summer values, while the statistical sig-
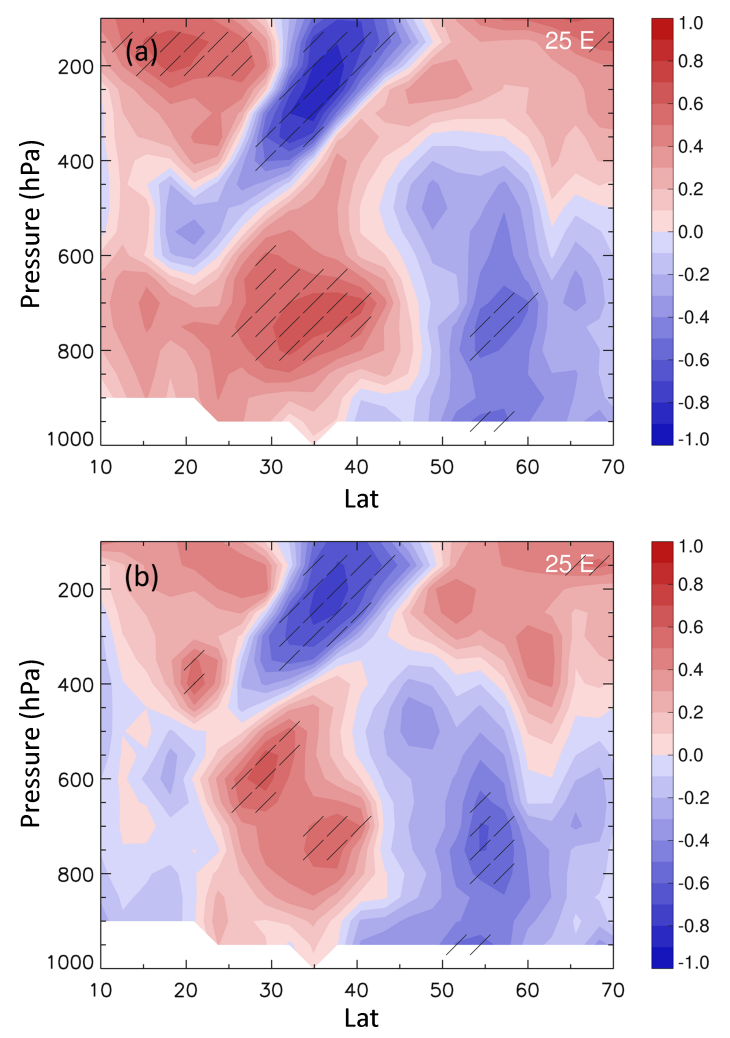

Figure 10. Latitude-pressure cross sections at $25^{\circ} \mathrm{E}$ of the correlation coefficient between the mean July-August interannual time series (1998-2013) of (a) tropopause fold frequency over SB and EMAC-simulated $\mathrm{O}_{3}$ s and (b) near-surface ozone at Finokalia and EMAC-simulated $\mathrm{O}_{3}$ s. Areas featuring correlation coefficients that are statistically significant at the $95 \%$ confidence level are hatched.

nificance of the trends is assessed using the Mann-Kendall test (Press et al., 1992) at the $95 \%$ confidence level. During summer, an elongated zone of positive fold frequency trends is detected across the EM, Turkey and the Caspian Sea, with values of up to $0.3 \%$ year $^{-1}$ (Fig. 11a). Similar positive shallow fold (with the depth of the fold ranging between 50 and $200 \mathrm{hPa}$ ) frequency trends during July-August of the period 1979-2012 have been reported by Tyrlis et al. (2014) using the ERA-Interim reanalysis data. The spatial distribution of $\mathrm{O}_{3}$ s trends during summer at $400 \mathrm{hPa}$ (Fig. 11b) indicates a distinct area of positive trends mostly over EMME, while towards lower tropospheric levels at 500, 600 and $700 \mathrm{hPa}$ the positive trend signal remains but attenuates (Fig. 11c, d and e). This increase in summertime EMAC-simulated $\mathrm{O}_{3} \mathrm{~s}$ may be associated with the aforementioned positive trends in fold frequency, as no significant trend in ozone total column (not shown) was found during summer over the EMME region. Our results are in line with Ordóñez et al. (2007) who pointed out that both the effects of stratospheric ozone and STT changes need to be represented accurately in models in order to describe the evolution of the background tropospheric ozone. 

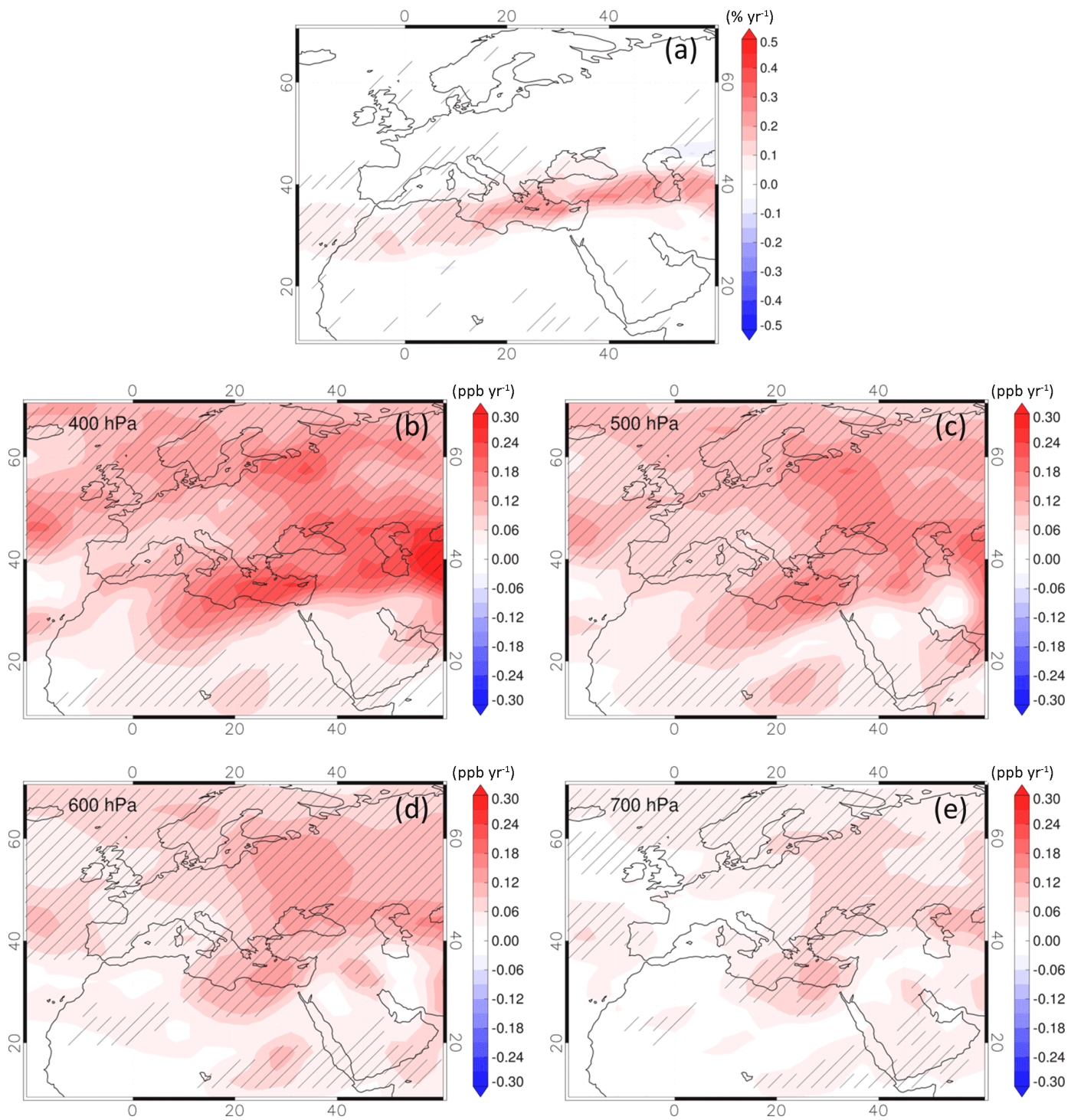

Figure 11. Trends of (a) JJA tropopause fold frequency $\left(\% \mathrm{yr}^{-1}\right)$ and JJA EMAC-simulated $\mathrm{O}_{3} \mathrm{~s}\left(\mathrm{ppb} \mathrm{yr}^{-1}\right)$ at (b) $400 \mathrm{hPa}$, (c) $500 \mathrm{hPa}^{-}$ (d) $600 \mathrm{hPa}$ and (e) $700 \mathrm{hPa}$ during the period 1979-2013. Areas featuring trends that are statistically significant at the $95 \%$ confidence level are hatched.

\section{Conclusions}

We investigated the role of tropopause folds in the formation of the summertime ozone pool over the EMME with the aid of simulations covering the period 1979-2013 by the atmospheric chemistry-climate model EMAC. Tropopause fold events in EMAC simulations were identified with the aid of the updated 3-D labeling algorithm (Škerlak et al., 2014) initially developed by Sprenger et al. (2003). The most noteworthy results in this study can be summarized as follows.

- A summertime hot spot of tropopause fold occurrence is identified in EMAC simulations over the EMME region, which agrees with the results of previous studies (Sprenger et al., 2003; Tyrlis et al., 2014; Škerlak et al.,
2015), indicating that the fold activity during summer over the region is well captured by the EMAC model.

- A distinct pool of high ozone concentrations is found in the middle troposphere over the EMME during the selected fold events. Moreover, the EMAC-simulated $\mathrm{O}_{3} / \mathrm{O}_{3} \mathrm{~s}$ ratio, averaged over all the selected fold events, implies a significant contribution of stratospheric ozone to the high tropospheric ozone mixing ratios over the EMME, even in the lower free troposphere.

- The pool of high tropospheric ozone over the EMME is a clear and permanent feature during summer, as was also pointed out by Zanis et al. (2014). The anomalies of EMAC-simulated $\mathrm{O}_{3}$ and $\mathrm{O}_{3}$ s during the selected fold 
events relative to the remainder of summer time steps reveal the key role of tropopause folds in stratospheric ozone-rich air mass transport into the troposphere. A considerable enhancement for both $\mathrm{O}_{3}$ and $\mathrm{O}_{3}$ s is identified in the middle troposphere over the EMME, extending down to the lower free troposphere, as a result of the fold activity over the region.

- In agreement with Zanis et al. (2014), the location of the ozone maximum during the selected fold events shifts towards the southeast with decreasing altitude. The contribution of tropopause folds in mid-tropospheric and lower tropospheric ozone seems to be most significant over the southeastern Mediterranean, as a result of the vertical downward transport of stratospheric ozone and the prevailing northwesterly flow in the middle and the lower free troposphere during summer.

- A year-to-year analysis indicates a relation between the observed surface ozone at Finokalia with both tropopause fold frequency and tropospheric ozone of stratospheric origin in the middle and the lower free troposphere over the EM, as the corresponding correlation coefficients were found to be positive and statistically significant. Hence, tropopause folds over the southern Balkans and $\mathrm{O}_{3} \mathrm{~s}$ at $700 \mathrm{hPa}$ over the EM explain 41 and $27 \%$, respectively, of the interannual variability of the mean July-August values of surface ozone at Finokalia for the time period 1998-2013.

- Finally, the upward trend of EMAC-simulated $\mathrm{O}_{3} \mathrm{~S}$ in the upper and the middle troposphere during summer over the EMME appears to be partly controlled by the corresponding trend in tropopause fold frequency. Taken together, this suggests that tropopause folds and tropospheric ozone with stratospheric origin have a greater impact on summertime near-surface ozone over the EM than previously thought, and contribute significantly to near-surface ozone interannual variability.

\section{Data availability}

EMEP data are available at http://www.nilu.no/projects/ccc/ emepdata.html (Tørseth et al., 2012). WOUDC data are available at http://woudc.org (WMO/GAW Ozone Monitoring Community, 2015).

The Supplement related to this article is available online at doi:10.5194/acp-16-14025-2016-supplement.
Acknowledgements. The model simulations were performed at the German Climate Computing Center (DKRZ) with support from the Bundesministerium für Bildung und Forschung (BMBF). DKRZ and its scientific steering committee are gratefully acknowledged for providing the HPC and data archiving resources for the consortial project ESCiMo (Earth System Chemistry integrated Modelling). We would like to acknowledge Patrick Jöckel for his contribution to the ESCiMo simulations and the EMAC model development. The authors also thank Nikos Mihalopoulos for provision of the ozone data from Finokalia station, Crete.

The article processing charges for this open-access publication were covered by the Max Planck Society.

Edited by: B. N. Duncan

Reviewed by: two anonymous referees

\section{References}

Akritidis, D., Zanis, P., Pytharoulis, I., Mavrakis, A., and Karacostas, T.: A deep stratospheric intrusion event down to the earth's surface of the megacity of Athens, Meteorol. Atmos. Phys., 109, 9-18, 2010.

Anagnostopoulou, C., Zanis, P., Katragkou, E., Tegoulias, I., and Tolika, K.: Recent past and future patterns of the Etesian winds based on regional scale climate model simulations, Clim. Dynam., 42, 1819-1836, 2014.

Appenzeller, C. and Davies, H.: Structure of stratospheric intrusions into the troposphere, Nature, 358, 570-572, 1992.

Carapiperis, L. N.: On the periodicity of the Etesians in Athens, Weather, 6, 378-379, 1951.

Crutzen, P. J.: Photochemical reactions initiated by and influencing ozone in unpolluted tropospheric air, Tellus, 26, 47-57, 1974.

Crutzen, P. J.: Tropospheric ozone: An overview, in: Tropospheric ozone, edited by: Isaksen, I. S. A., D. Reidel Publ. Co., Dordrecht, the Netherlands, 3-32, 1988.

Danielsen, E. F.: Stratospheric-tropospheric exchange based on radioactivity, ozone and potential vorticity, J. Atmos. Sci., 25, 502518, 1968.

Danielsen, E. F. and Mohnen, V. A.: Project Dustorm report: Ozone transport, in situ measurements, and meteorological analyses of tropopause folding, J. Geophys. Res., 82, 5867-5877, 1977.

Dee, D. P., Uppala, S. M., Simmons, A. J., Berrisford, P., Poli, P., Kobayashi, S., Andrae, U., Balmaseda, M. A., Balsamo, G., Bauer, P., Bechtold, P., Beljaars, A. C. M., van de Berg, L., Bidlot, J., Bormann, N., Delsol, C., Dragani, R., Fuentes, M., Geer, A. J., Haimberger, L., Healy, S. B., Hersbach, H., Holm, E. V., Isaksen, L., Kallberg, P., Kohler, M., Matricardi, M., McNally, A. P., Monge-Sanz, B. M., Morcrette, J. J., Park, B. K., Peubey, C., de Rosnay, P., Tavolato, C., Thepaut, J. N., and Vitart, F.: The ERA-Interim reanalysis: Configuration and performance of the data assimilation system, Q. J. Roy. Meteor. Soc., 137, 553-597, 2011.

Doche, C., Dufour, G., Foret, G., Eremenko, M., Cuesta, J., Beekmann, M., and Kalabokas, P.: Summertime tropospheric-ozone variability over the Mediterranean basin observed with IASI, Atmos. Chem. Phys., 14, 10589-10600, doi:10.5194/acp-1410589-2014, 2014. 
Forster, C. and Wirth, V.: Radiative decay of idealized stratospheric filaments in the troposphere, J. Geophys. Res.-Atmos., 105, 10169-10184, 2000.

Galani, E., Balis, D., Zanis, P., Zerefos, C., Papayannis, A., Wernli, H., and Gerasopoulos, E.: Observations of stratosphereto-troposphere transport events over the eastern Mediterranean using a ground-based lidar system, J. Geophys. Res.-Atmos., 108, 8527, doi:10.1029/2002JD002596, 2003.

Gerasopoulos, E., Kouvarakis, G., Vrekoussis, M., Kanakidou, M., and Mihalopoulos, N.: Ozone variability in the marine boundary layer of the eastern Mediterranean based on 7year observations, J. Geophys. Res.-Atmos., 110, D15309, doi:10.1029/2005JD005991, 2005.

Gerasopoulos, E., Zanis, P., Papastefanou, C., Zerefos, C. S., Ioannidou, A., and Wernli, H.: A complex case study of down to the surface intrusions of persistent stratospheric air over the Eastern Mediterranean, Atmos. Environ., 40, 4113-4125, 2006.

Hauglustaine, D. and Brasseur, G. P.: Evolution of tropospheric ozone under anthropogenic activities and associated radiative forcing of climate, J. Geophys. Res.-Atmos., 106, 32337-32360, 2001.

Holton, J. R., Haynes, P. H., McIntyre, M. E., Douglass, A. R., Rood, R. B., and Pfister, L.: Stratosphere-troposphere exchange, Rev. Geophys., 33, 403-439, 1995.

Im, U., Markakis, K., Poupkou, A., Melas, D., Unal, A., Gerasopoulos, E., Daskalakis, N., Kindap, T., and Kanakidou, M.: The impact of temperature changes on summer time ozone and its precursors in the Eastern Mediterranean, Atmos. Chem. Phys., 11, 3847-3864, doi:10.5194/acp-11-3847-2011, 2011.

Jöckel, P., Tost, H., Pozzer, A., Kunze, M., Kirner, O., Brenninkmeijer, C. A. M., Brinkop, S., Cai, D. S., Dyroff, C., Eckstein, J., Frank, F., Garny, H., Gottschaldt, K.-D., Graf, P., Grewe, V., Kerkweg, A., Kern, B., Matthes, S., Mertens, M., Meul, S., Neumaier, M., Nützel, M., Oberländer-Hayn, S., Ruhnke, R., Runde, T., Sander, R., Scharffe, D., and Zahn, A.: Earth System Chemistry integrated Modelling (ESCiMo) with the Modular Earth Submodel System (MESSy) version 2.51, Geosci. Model Dev., 9, 1153-1200, doi:10.5194/gmd-9-1153-2016, 2016.

Kalabokas, P. D. and Repapis, C. C.: A climatological study of rural surface ozone in central Greece, Atmos. Chem. Phys., 4, 11391147, doi:10.5194/acp-4-1139-2004, 2004.

Kalabokas, P. D., Cammas, J.-P., Thouret, V., Volz-Thomas, A., Boulanger, D., and Repapis, C. C.: Examination of the atmospheric conditions associated with high and low summer ozone levels in the lower troposphere over the eastern Mediterranean, Atmos. Chem. Phys., 13, 10339-10352, doi:10.5194/acp-1310339-2013, 2013.

Kanakidou, M., Mihalopoulos, N., Kindap, T., Im, U., Vrekoussis, M., Gerasopoulos, E., Dermitzaki, E., Unal, A., Kocak, M., Markakis, K., Melas, D., Kouvarakis, G., Youssef, A. F., Richter, A., Hatzianastassiou, N., Hilboll, A., Ebojie, F., von Savigny, C., Ladstaetter Weissenmayer, A., Burrows, J., and Moubasher, H.: Megacities as hot spots of air pollution in the East Mediterranean, Atmos. Environ., 45, 1223-1235, 2011.

Kentarchos, A., Roelofs, G., and Lelieveld, J.: Simulation of extratropical synoptic-scale stratosphere-troposphere exchange using a coupled chemistry GCM: sensitivity to horizontal resolution, J. Atmos. Sci., 57, 2824-2838, 2000.
Kourtidis, K., Zerefos, C., Rapsomanikis, S., Simeonov, V., Balis, D., Perros, P. E., Thomson A. M., Witte, J., Calpini, B., Sharobiem, W. M., Papayiannis, A., Mihalopoulos, N., and Drakou, R.: Regional levels of ozone in the troposphere over eastern Mediterranean, J. Geophys. Res.-Atmos., 107, 8140, doi:10.1029/2000JD000140, 2002.

Kouvarakis, G., Tsigaridis, K., Kanakidou, M., and Mihalopoulos, N.: Temporal variations of surface regional background ozone over Crete Island in the southeast Mediterranean, J. Geophys. Res.-Atmos., 105, 4399-4407, 2000.

Kouvarakis, G., Vrekoussis, M., Mihalopoulos, N., Kourtidis, K., Rappenglueck, B., Gerasopoulos, E., and Zerefos, C.: Spatial and temporal variability of tropospheric ozone $\left(\mathrm{O}_{3}\right)$ in the boundary layer above the Aegean Sea (eastern Mediterranean), J. Geophys. Res.-Atmos., 107, 8137, doi:10.1029/2000JD000081, 2002.

Lacis, A. A., Wuebbles, D. J., and Logan, J. A.: Radiative forcing of climate by changes in the vertical distribution of ozone, J. Geophys. Res.-Atmos., 95, 9971-9981, 1990.

Lelieveld, J. and Dentener, F. J.: What controls tropospheric ozone?, J. Geophys. Res.-Atmos., 105, 3531-3551, 2000.

Lelieveld, J., Berresheim, H., Borrmann, S., Crutzen, P. J., Dentener, F. J., Fischer, H., de Gouw, J., Feichter, J., Flatau, P., Heland, J., Holzinger, R., Korrmann, R., Lawrence, M., Levin, Z., Markowicz, K., Mihalopoulos, N., Minikin, A., Ramanathan, V., de Reus, M., Roelofs, G.-J., Scheeren, H. A., Sciare, J., Schlager, H., Schultz, M., Siegmund, P., Steil, B., Stephanou, E., Stier, P., Traub, M., Williams, J., and Ziereis, H.: Global air pollution crossroads over the Mediterranean, Science, 298, 794-799, 2002.

Lelieveld, J., Hoor, P., Jöckel, P., Pozzer, A., Hadjinicolaou, P., Cammas, J.-P., and Beirle, S.: Severe ozone air pollution in the Persian Gulf region, Atmos. Chem. Phys., 9, 1393-1406, doi:10.5194/acp-9-1393-2009, 2009.

Li, Q., Jacob, D. J., Logan, J. A., Bey, I., Yantosca, R. M., Liu, H., Martin, R. V., Fiore, A. M., Field, B. D, Duncan, B. N., and Thouret, V.: A tropospheric ozone maximum over the Middle East, Geophys. Res. Lett., 28, 3235-3238, 2001.

Liakakou, E., Vrekoussis, M., Bonsang, B., Donousis, C., Kanakidou, M., and Mihalopoulos, N.: Isoprene above the Eastern Mediterranean: Seasonal variation and contribution to the oxidation capacity of the atmosphere, Atmos. Environ., 41, 10021010, 2007.

Lin, M., Fiore, A. M., Cooper, O. R., Horowitz, L. W., Langford, A. O., Levy, H., Johnson, B. J., Naik, V., Oltmans, S. J., and Senff, C. J.: Springtime high surface ozone events over the western United States: Quantifying the role of stratospheric intrusions, J. Geophys. Res.-Atmos., 117, D00V22, doi:10.1029/2012JD018151, 2012.

Lin, M., Fiore, A. M., Horowitz, L. W., Langford, A. O., Oltmans, S. J., Tarasick, D., and Rieder, H. E.: Climate variability modulates western US ozone air quality in spring via deep stratospheric intrusions, Nat. Commun., 6, 7105, doi:10.1038/ncomms8105, 2015.

Liu, J. J., Jones, D., Worden, J. R., Noone, D., Parrington, M., and Kar, J.: Analysis of the summertime buildup of tropospheric ozone abundances over the Middle East and North Africa as observed by the Tropospheric Emission Spectrometer instrument, J. Geophys. Res.-Atmos., 114, D05304, doi:10.1029/2008JD010993, 2009. 
Liu, J. J., Jones, D., Zhang, S., and Kar, J.: Influence of interannual variations in transport on summertime abundances of ozone over the Middle East, J. Geophys. Res.-Atmos., 116, D20310, doi:10.1029/2011JD016188, 2011.

Ordóñez, C., Brunner, D., Staehelin, J., Hadjinicolaou, P., Pyle, J., Jonas, M., Wernli, H., and Prévôt, A.: Strong influence of lowermost stratospheric ozone on lower tropospheric background ozone changes over Europe, Geophys. Res. Lett., 34, L07805, doi:10.1029/2006GL029113, 2007.

Penkett, S.: Indications and causes of ozone increase in the troposphere, in: The changing atmosphere, edited by: Rowland, F. S. and Isaksen, I. S. A., J. Wiley \& Sons, New York, NY, USA, 91-103, 1988.

Poupkou, A., Zanis, P., Nastos, P., Papanastasiou, D., Melas, D., Tourpali, K., and Zerefos, C.: Present climate trend analysis of the Etesian winds in the Aegean Sea, Theor. Appl. Climatol., 106, 459-472, 2011.

Press, W. H., Teukolsky, S. A., Vetterling, W. T., and Flannery, B. P.: Numerical recipes in Fortran 77: the art of scientific computing, Cambridge University Press, New York, NY, USA, 1992.

Repapis, C., Zerefos, C., and Tritakis, B.: On the Etesians over the Aegean, Proc. Acad. Athens, 52, 572-606, 1977.

Richards, N. A. D., Arnold, S. R., Chipperfield, M. P., Miles, G., Rap, A., Siddans, R., Monks, S. A., and Hollaway, M. J.: The Mediterranean summertime ozone maximum: global emission sensitivities and radiative impacts, Atmos. Chem. Phys., 13, 2331-2345, doi:10.5194/acp-13-2331-2013, 2013.

Rodwell, M. and Hoskins, B.: Subtropical anticyclones and summer monsoons, J. Climate, 14, 3192-3211, 2001.

Rodwell, M. J. and Hoskins, B. J.: Monsoons and the dynamics of deserts, Q. J. Roy. Meteor. Soc., 122, 1385-1404, 1996.

Roeckner, E., Brokopf, R., Esch, M., Giorgetta, M., Hagemann, S., Kornblueh, L., Manzini, E., Schlese, U., and Schulzweida, U.: Sensitivity of simulated climate to horizontal and vertical resolution in the ECHAM5 atmosphere model, J. Climate, 19, 37713791, 2006.

Roelofs, G.-J. and Lelieveld, J.: Model study of the influence of cross-tropopause $\mathrm{O}_{3}$ transports on tropospheric $\mathrm{O}_{3}$ levels, Tellus B, 49, 38-55, 1997.

Roelofs, G. J., Scheeren, H. A., Heland, J., Ziereis, H., and Lelieveld, J.: A model study of ozone in the eastern Mediterranean free troposphere during MINOS (August 2001), Atmos. Chem. Phys., 3, 1199-1210, doi:10.5194/acp-3-1199-2003, 2003.

Safieddine, S., Boynard, A., Coheur, P.-F., Hurtmans, D., Pfister, G., Quennehen, B., Thomas, J. L., Raut, J.-C., Law, K. S., Klimont, Z., Hadji-Lazaro, J., George, M., and Clerbaux, C.: Summertime tropospheric ozone assessment over the Mediterranean region using the thermal infrared IASI/MetOp sounder and the WRF-Chem model, Atmos. Chem. Phys., 14, 1011910131, doi:10.5194/acp-14-10119-2014, 2014.

Shapiro, M.: Turbulent mixing within tropopause folds as a mechanism for the exchange of chemical constituents between the stratosphere and troposphere, J. Atmos. Sci., 37, 994-1004, 1980.

Škerlak, B., Sprenger, M., and Wernli, H.: A global climatology of stratosphere-troposphere exchange using the ERA-Interim data set from 1979 to 2011, Atmos. Chem. Phys., 14, 913-937, doi:10.5194/acp-14-913-2014, 2014.
Škerlak, B., Sprenger, M., Pfahl, S., Tyrlis, E., and Wernli, H.: Tropopause Folds in ERA-Interim: Global Climatology and Relation to Extreme Weather Events, J. Geophys. Res.-Atmos., 120, 4860-4877, doi:10.1002/2014JD022787, 2015.

Solomon, S., Qin, D., Manning, M., Chen, Z., Marquis, M., Averyt, K., Tignor, M., and Miller, H. L.: IPCC, Climate change 2007: the physical science basis. Contribution of working group I to the fourth assessment report of the intergovernmental panel on climate change, Cambridge University Press, New York, NY, USA, 2007.

Sprenger, M., Croci Maspoli, M., and Wernli, H.: Tropopause folds and cross-tropopause exchange: A global investigation based upon ECMWF analyses for the time period March 2000 to February 2001, J. Geophys. Res.-Atmos., 108, 8518, doi:10.1029/2002JD002587, 2003.

Stohl, A., Eckhardt, S., Forster, C., James, P., and Spichtinger, N.: On the pathways and timescales of intercontinental air pollution transport, J. Geophys. Res.-Atmos., 107, 4684, doi:10.1029/2001JD001396, 2002.

Stohl, A., Bonasoni, P., Cristofanelli, P., Collins,W., Feichter, J., Frank, A., Forster, C., Gerasopoulos, E., Gaggeler, H., James, P., Kentarchos, T., Kromp-Kolb, H., Kruger, B., Land, C., Meloen, J., Papayannis, A., Priller, A., Seibert, P., Sprenger, M., Roelofs, G., Scheel, H., Schnabel, C., Siegmund, P., Tobler, L., Trickl, T., Wernli, H., Wirth, V., Zanis, P., and Zerefos, C.: Stratosphere-troposphere exchange: A review, and what we have learned from STACCATO, J. Geophys. Res.-Atmos., 108, 8516, doi:10.1029/2002JD002490, 2003.

Tombrou, M., Bossioli, E., Kalogiros, J., Allan, J. D., Bacak, A., Biskos, G., Coe, H., Dandou, A., Kouvarakis, G., Mihalopoulos, N., Percival, C. J., Protonotariou, A. P., and Szabó-Takács, B.: Physical and chemical processes of air masses in the Aegean Sea during Etesians: Aegean-GAME airborne campaign, Sci. Total Environ., 506-507, 201-216, 2015.

Tørseth, K., Aas, W., Breivik, K., Fjæraa, A. M., Fiebig, M., Hjellbrekke, A. G., Lund Myhre, C., Solberg, S., and Yttri, K. E.: Introduction to the European Monitoring and Evaluation Programme (EMEP) and observed atmospheric composition change during 1972-2009, Atmos. Chem. Phys., 12, 5447-5481, doi:10.5194/acp-12-5447-2012, 2012.

Traub, M. and Lelieveld, J.: Cross-tropopause transport over the eastern Mediterranean, J. Geophys. Res.-Atmos., 108, 4712, doi:10.1029/2003JD003754, 2003.

Tyrlis, E. and Lelieveld, J.: Climatology and Dynamics of the Summer Etesian Winds over the Eastern Mediterranean, J. Atmos. Sci., 70, 3374-3396, 2013.

Tyrlis, E., Lelieveld, J., and Steil, B.: The summer circulation over the eastern Mediterranean and the Middle East: influence of the South Asian monsoon, Clim. Dynam., 40, 1103-1123, 2013.

Tyrlis, E., Škerlak, B., Sprenger, M., Wernli, H., Zittis, G., and Lelieveld, J.: On the linkage between the Asian summer monsoon and tropopause fold activity over the eastern Mediterranean and the Middle East, J. Geophys. Res.-Atmos., 119, 3202-3221, 2014.

WMO/GAW Ozone Monitoring Community: World Meteorological Organization-Global Atmosphere Watch Program (WMOGAW)/World Ozone and Ultraviolet Radiation Data Centre (WOUDC), Data, available at: doi:10.14287/10000001, last access: 2 November 2015. 
Zanis, P., Trickl, T., Stohl, A., Wernli, H., Cooper, O., Zerefos, C., Gaeggeler, H., Schnabel, C., Tobler, L., Kubik, P. W., Priller, A., Scheel, H. E., Kanter, H. J., Cristofanelli, P., Forster, C., James, P., Gerasopoulos, E., Delcloo, A., Papayannis, A., and Claude, H.: Forecast, observation and modelling of a deep stratospheric intrusion event over Europe, Atmos. Chem. Phys., 3, 763-777, doi:10.5194/acp-3-763-2003, 2003.

Zanis, P., Hadjinicolaou, P., Pozzer, A., Tyrlis, E., Dafka, S., Mihalopoulos, N., and Lelieveld, J.: Summertime free-tropospheric ozone pool over the eastern Mediterranean/Middle East, Atmos. Chem. Phys., 14, 115-132, doi:10.5194/acp-14-115-2014, 2014.

Zerefos, C. S., Kourtidis, K. A., Melas, D., Balis, D., Zanis, P., Katsaros, L., Mantis, H. T., Repapis, C., Isaksen, I., Sundet, J., Herman, J., Bhartia, P. K., and Calpini, B.: Photochemical Activity and Solar Ultraviolet Radiation (PAUR) Modulation Factors: An overview of the project, J. Geophys. Res.-Atmos., 107, 8134, doi:10.1029/2000JD000134, 2002.
Zhang, L., Jacob, D. J., Yue, X., Downey, N. V., Wood, D. A., and Blewitt, D.: Sources contributing to background surface ozone in the US Intermountain West, Atmos. Chem. Phys., 14, 52955309, doi:10.5194/acp-14-5295-2014, 2014.

Ziv, B., Saaroni, H., and Alpert, P.: The factors governing the summer regime of the eastern Mediterranean, Int. J. Climatol., 24, 1859-1871, 2004. 